
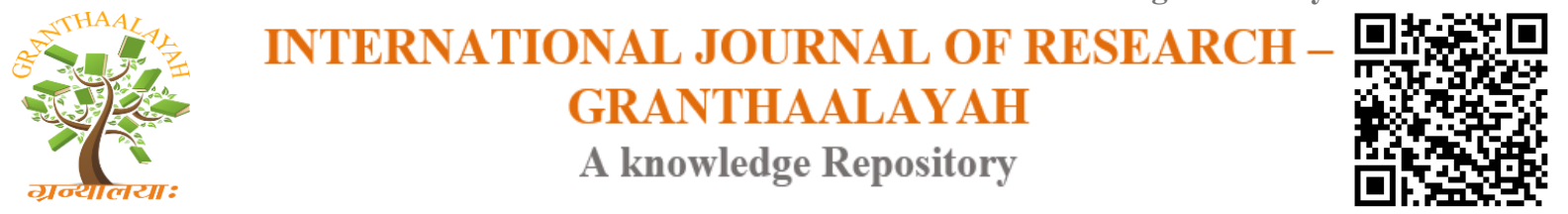

Social

\title{
PERCEPTION OF YOUTH ON MARRIAGE PRACTICES: A STUDY IN DODDA BIRANA KUPPE GRAM PANCHAYAT, H D KOTE TALUK, MYSURU DISTRICT
}

\author{
Dr. Mohan A.K ${ }^{* 1}$, Gangotri Dash ${ }^{2}$ \\ ${ }^{*}$ Assistant Professor, DoS in Social Work, Manasagangotri, University of Mysore, Mysuru, \\ INDIA \\ ${ }^{2}$ Research Scholar, DoS in Social Work, Manasagangotri, University of Mysore, Mysuru, INDIA
}

\begin{abstract}
Marital relationship not only provides sanction to family life but also affects the life decisions and satisfaction of people in this bond. The ritual associated with marriage has direct impact on wellbeing of persons in this relationship. Although debates and discussions on child marriage and restrictions for widow etc. have brought legislations to prohibit such practices but still these are not completely eradicated. Hence, to make future free from such evils and to understand the marital satisfaction, it is essential to understand the perception of young people on the marriage rituals of their communities and also their expectations. This study focused on the perception on marriage rituals of tribal youth living in Dodda Birana Kuppe Gram Panchayat of $\mathrm{H} D$ Kote Taluk, Mysore district. Research has taken gender and educational qualification as factors to understand association of these factors with perception and knowledge of youth about marriage. Based on the finding and suggestions of community youth, study has emphasized the importance of counselling and education.
\end{abstract}

Keywords:

Marriage Practices, Marital relationship, child marriage, marriage rituals.

Cite This Article: Dr. Mohan A.K, Gangotri Dash, "PERCEPTION OF YOUTH ON MARRIAGE PRACTICES: A STUDY IN DODDA BIRANA KUPPE GRAM PANCHAYAT, H D KOTE TALUK, MYSURU DISTRICT" International Journal of Research - Granthaalayah, Vol. 4, No. 3 (2016): 42-52.

\section{INTRODUCTION}

Marriage is an essential social institution. It provides social approval to start family life. Although it is universal but rituals, practices and types of marriage differs in different communities. India is known for its diversity and different groups, castes and religions observe different rituals to celebrate their social ceremonies. Various demographic factors like gender, caste, place of living, education level etc. influence perception towards marriage. Studies show that young male and female (Bhale, 2013) and respondents with different education level (Misra, 
et. al 2015) provide different opinion about the issues associated with marriage like caste, economic condition, parents' permission etc. Early marriage has been reported in many survey at national as well as sub national level. According to National Family Health Survey-3 more than one fourth of women aged 20-49 years were married before age 15 and more than half (58\%) were married before the legal age of 18 years (UNICEF 2013). Although there is awareness about issues associated with child marriage but there is lack of sensitivity regarding what is its impact on the youth (Mitra \& Parasuraman 2015). As different groups have different practices, different types of tribes of India also follow different marriage customs. In some tribal culture there is freedom to choose partner and some other culture deny. Among Bhutias and Bodhs child marriage and dowry systems are not known (Bhasin 2007).

Considering the changing needs and welfare of people social legislations were framed to regulate the marriage system which restricts some of the harmful rituals. However due to cultural lag many communities are not able to accept the rules and, as a result of which rituals like child marriage, forced marriage are still in practice. Actual changes can be brought if the perception of youth towards marriage and their expectations from marriage be understood properly. There is very little knowledge about the extent to which young people themselves are involved in the decision making process. A study by Upadhyay and Gupta (2013) revealed that in India there was wide regional disparity with regard to role of youth in their marriage related process.

Keeping all these things in consideration the current study intended to understand the marriage practices of tribal people living in Dodda Birana Kuppe GP of H.D Kote taluk, Mysuru district and mainly concentrated on the knowledge of youth about legal provisions related to marriage and their perception about marriage.

\section{METHODOLOGY}

A descriptive study design was adopted to study the perception of youth on marriage and associated rituals. Data collection was done from the young people between age 18 to 35 of Dodda Birana Kuppe Gram Panchayat of H D Kote Taluk, Mysore district. Population of the studied Gram Panchayat is 5054 spread over ten villages (www.panchamitra.kar.nic.in). Respondents were selected using convenience sampling technique from all the ten villages and structured interview schedule was used to record the responses. Total 120 respondents participated in the study, out of which 112 response were included for analysis. 8 schedules were rejected due to incomplete information. The entire schedule was serially numbered and the data were coded with a view to bring about homogeneity in answers and to facilitate interpretation. Mainly the classification was done on the basis of gender and education level of respondents. As the sample size both in gender and education level was uneven the percentage was taken to their respective group totals and not to the entire population. SPSS was used for data analysis. As there were open ended and suggestive questions, qualitative understanding and analysis was done for these responses.

\section{OBJECTIVES AND HYPOTHESES}

1. To know the community attitude and practices towards marriage from youth's point of view 
$\mathrm{H}_{01}=$ There is no significant difference in marriage age between male and female

$\mathrm{H}_{02}=$ There is no significant difference in marriage age among youth with different level of education.

2. To find out the youth's awareness about legal provisions related to marriage

$\mathrm{H}_{03}=$ There is no significant difference in awareness of marital laws among youth of different level of education.

$\mathrm{H}_{04}=$ There is no significant difference in awareness of marital divorce among youth of different level of education.

3. To understand the perception of youth about celebrating marriage ritual

$\mathrm{H}_{05}=$ There is no significant difference in perception towards celebration of marriage ceremony between male and female.

4. To know the expectations of youth from marital relationship

$\mathrm{H}_{06}=$ There is no significant difference in opinion on remarriage between male and female.

$\mathrm{H}_{07}=$ There is no significant difference in opinion on employment status of spouse between male and female

$\mathrm{H}_{08}=$ There is no significant difference in acceptance of physically challenged spouse between male and female.

DEMOGRAPHIC DETAILS

Table 1: Details of respondents

\begin{tabular}{|l|l|l|l|}
\hline Details & Categories & Count & Percentage \\
\hline \multirow{5}{*}{ Hadi Name } & Hosur & 6 & 5.4 \\
\cline { 2 - 4 } & Vadakemalu & 4 & 0.9 \\
\cline { 2 - 4 } & T Hosahalli & 5 & 4.5 \\
\cline { 2 - 4 } & Bhavali & 15 & 13.4 \\
\cline { 2 - 4 } & Anemala & 21 & 18.8 \\
\cline { 2 - 4 } & Mooleyoru & 10 & 7.1 \\
\cline { 2 - 4 } & B C Koppe & 15 & 13.4 \\
\cline { 2 - 4 } & Machur & 11 & 9.8 \\
\cline { 2 - 4 } & Golur & 15 & 13.4 \\
\cline { 2 - 4 } & Karahadi & 10 & 8.9 \\
\cline { 2 - 4 } & Total & $\mathbf{1 1 2}$ & $\mathbf{1 0 0}$ \\
\hline \multirow{5}{*}{ Clan } & Jenu Kuruba & 70 & 62.5 \\
\cline { 2 - 4 } & Bodagas & 2 & 1.8 \\
\cline { 2 - 4 } & Yaiauas & 4 & 3.6 \\
\cline { 2 - 4 } & Herava & 8 & 7.1 \\
\cline { 2 - 4 } & Beda & 10 & 8.9 \\
\cline { 2 - 4 } & Not answered & 18 & 16.1 \\
\cline { 2 - 4 } & Total & $\mathbf{1 1 2}$ & $\mathbf{1 0 0}$ \\
\hline \multirow{5}{*}{ Gender } & Male & 41 & 36.6 \\
\cline { 2 - 4 } & Female & 71 & 63.4 \\
\cline { 2 - 4 } & Total & $\mathbf{1 1 2}$ & 77.7 \\
\hline \multirow{5}{*}{} & Married & \\
\hline
\end{tabular}




\begin{tabular}{|l|l|l|l|}
\hline \multirow{3}{*}{ Marital Status } & Unmarried & 22 & 19.6 \\
\cline { 2 - 4 } & Widow & 3 & 2.7 \\
\cline { 2 - 4 } & Total & $\mathbf{1 1 2}$ & $\mathbf{1 0 0}$ \\
\hline \multirow{4}{*}{ Family Type } & \multirow{2}{*}{ Joint } & 15 & \\
& Nuclear & 97 & 13.4 \\
\cline { 2 - 4 } & Total & $\mathbf{1 1 2}$ & $\mathbf{1 0 0}$ \\
\hline \multirow{3}{*}{$\begin{array}{l}\text { Mncombly } \\
\text { Family }\end{array}$} & Below 3000 & 62 & 55.4 \\
\cline { 2 - 4 } & $3000-6000$ & 32 & 28.6 \\
\cline { 2 - 4 } & $6000-9000$ & 13 & 11.6 \\
\cline { 2 - 4 } & 10000 and above & 1 & 0.9 \\
\cline { 2 - 4 } & Not answered & 4 & 3.6 \\
\cline { 2 - 4 } & Total & $\mathbf{1 1 2}$ & $\mathbf{1 0 0}$ \\
\hline
\end{tabular}

Table 2: Gender wise education level of respondents

\begin{tabular}{|c|c|c|c|c|c|c|c|}
\hline & \multicolumn{6}{|c|}{ Education (Percentage) } & \multirow{2}{*}{$\begin{array}{l}\text { Total } \\
\text { (Percenta } \\
\text { ge) }\end{array}$} \\
\hline & Illiterate & Neo Literate & Primary & Upper Primary & High School & PUC & \\
\hline Male & $15(36$. & & $4(9.8)$ & & & $1(2$. & $41(100)$ \\
\hline Female & $35(49.3)$ & $6(8.5)$ & $11(15.5)$ & $9(12.7)$ & $7(9.9)$ & $3(4.2)$ & $71(100)$ \\
\hline otal & $50(44.6)$ & $12(10.7)$ & $15(13.4)$ & $16(14.3)$ & $15(13.4)$ & $4(3.6)$ & $112(100)$ \\
\hline
\end{tabular}

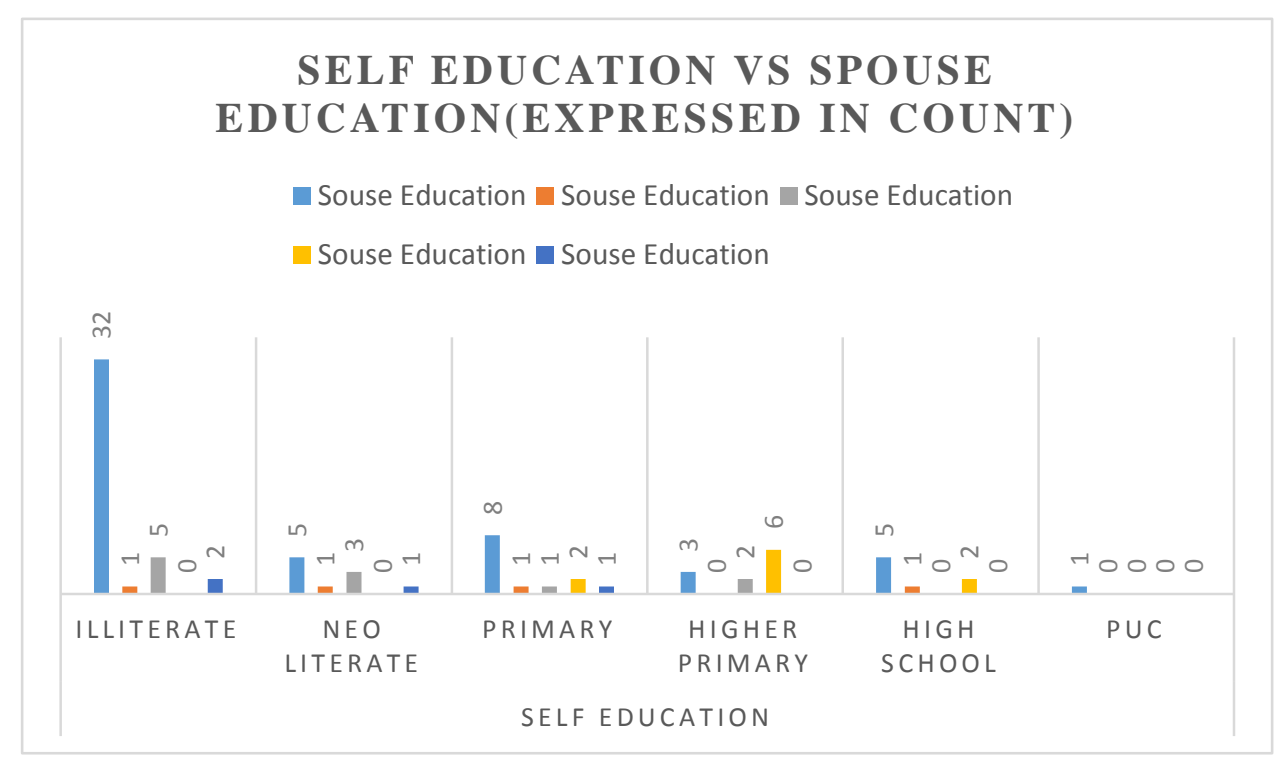

Graph 1: Comparison of respondent education level with spouse education

Both married and unmarried young people were included in the study from 10 villages (hadi) of Dodda Birana Koppe Gram Panchayat. From Bhavali (13.4), Anemal (18.8), B.C Koppe (13.4) and Golur (13.4) hadi more than $10 \%$ youth participated in the study. $62.5 \%$ respondent belongs 
to Jenukuruba clan. $77.7 \%$ respondents were married and $86.6 \%$ were living in nuclear families. The table no. 1 shows low education and economic status. The census report also reveals that 1238 persons out of 5054 are under BPL category and the literacy rate of the gram panchayat is only $32.13 \%$. 55.4\% respondents' monthly family income is less than Rs. 3000 . Majority $44.6 \%$ respondent are illiterate and $10.7 \%$ are neo literate. Among the respondents $49.3 \%$ females are illiterate and $36.6 \%$ males are illiterate. Not a single respondent has studied above pre university level. Graph no. 1 presents a comparative chart of respondents' education level with their spouse's education level. There is no particular trend of choosing spouse based on own education level.

\section{RESULTS AND DISCUSSIONS:}

\subsection{MARRIAGE PRACTICES IN COMMUNITY}

Table 3: Marriage age of respondents

\begin{tabular}{|l|l|l|}
\hline Gender & Male & Female \\
\hline Mean age at marriage & 20.36 & 16.38 \\
\hline Std. Deviation & 3.63 & 3.59 \\
\hline Minimum & 14 & 6 \\
\hline Maximum & 28 & 28 \\
\hline
\end{tabular}

Mean marriage age was found 20.3 and 16.3 for male and female respondents respectively. Both in case of male and female mean marriage age was less than the fixed legal age i.e. 21 for male and 18 for female. The range of marriage age of male respondents vary from 14 to 28 and female respondent vary from 6 to 28. Graph no. 2 shows that majority of female respondents $55 \%$ and male respondents $42.9 \%$ are married in the age between 16 to 20 . However, $91.6 \%$ female respondents got married before 20 and $53.6 \%$ male were married before age 20. Chi square test also reveals that there is significant difference between the marriage age of male and female but marriage age is not associated with level of education. This does not mean that education cannot be used as a strategy to reduce child marriage as none of the respondents have attended higher education.

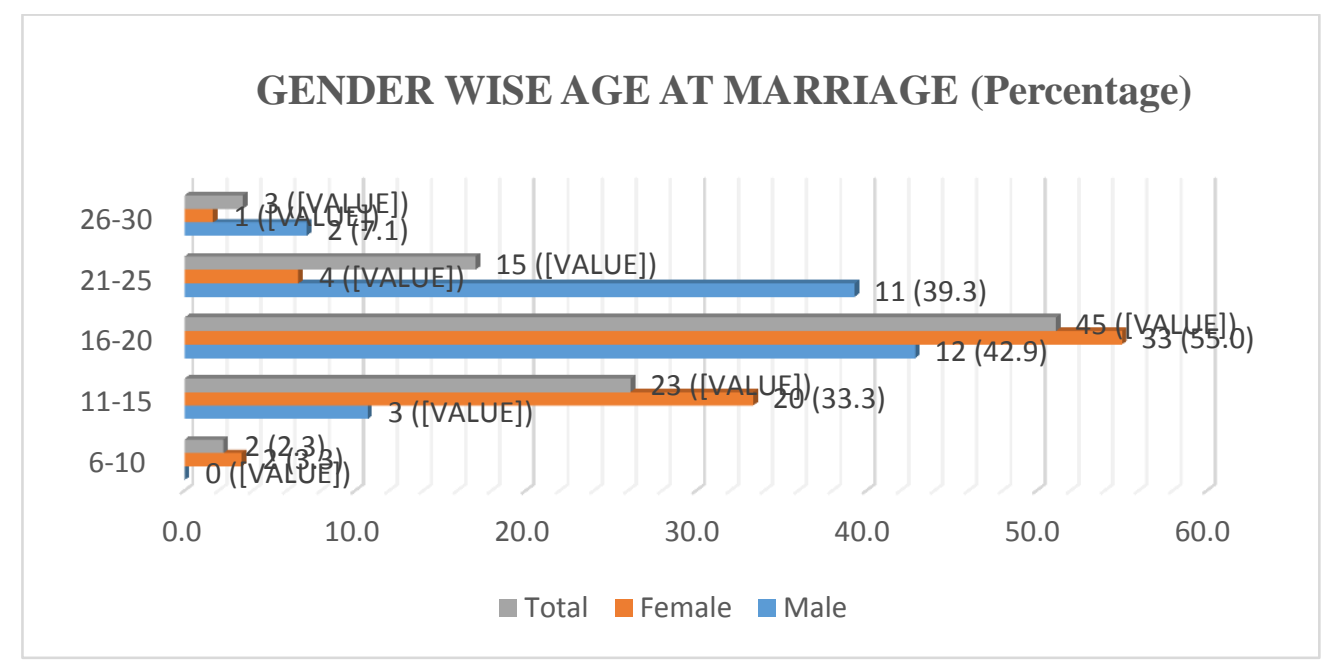

Graph 2: Gender wise marriage age 
$\mathrm{H}_{01}=$ There is no significant difference in marriage age between male and female

$\mathrm{p}$ value at degree of freedom 4 and significant level 0.05 is found 0.000 which is less than 0.05 . Hence $\mathrm{p}$ value is significant and null hypothesis is rejected.

Therefore, there is significant difference in marriage age between male and female

$\mathrm{H}_{02}=$ There is no significant difference in marriage age among youth with different level of education.

$\mathrm{p}$ value at degree of freedom 20 and significant level 0.05 is found 0.296 which is greater than 0.05 . Hence $\mathrm{p}$ value is not significant and null hypothesis is accepted.

Therefore, it is inferred that there is no significant difference in marriage age among youth with different level of education.

Table 4: Current practice of marriage in community as per the views of respondents

\begin{tabular}{|l|l|l|l|}
\hline \multirow{2}{*}{$\begin{array}{l}\text { Type of marriage } \\
\text { practice }\end{array}$} & \multicolumn{2}{|l|}{ Gender } & $\begin{array}{l}\text { Total } \\
\text { (Percentage) }\end{array}$ \\
\cline { 2 - 4 } Child marriage & Male (Percentage) & Female (Percentage) & $61(54.6)$ \\
\hline Adult marriage & $16(39.1)$ & $38(53.5)$ & $48(42.90$ \\
\hline Not answered & $2(4.8)$ & $32(45.07)$ & $3(2.6)$ \\
\hline Total & $\mathbf{4 1 ( 1 0 0 )}$ & $1(1.40)$ & $\mathbf{1 1 2 ( 1 0 0 )}$ \\
\hline Need of child marriage & $\mathbf{7 1 ( 1 0 0 )}$ & $\begin{array}{l}\text { Total } \\
\text { (Percentage) }\end{array}$ \\
\hline $\begin{array}{l}\text { Child marriage is } \\
\text { needed }\end{array}$ & Gender & Female (Percentage) & \\
\cline { 2 - 4 } & Male (Percentage) & $24(33.8)$ & $38(33.9)$ \\
\hline Yes & $14(34.3)$ & $47(66.2)$ & $2(1.8)$ \\
\hline No & $25(60.9)$ & 0 & $112(100)$ \\
\hline Not answered & $2(4.8)$ & $71(100)$ & \\
\hline Total & $41(100)$ & & \\
\hline
\end{tabular}

Child marriage is not a celebration rather it kills the childhood of a person and destroys adulthood. According to $54.6 \%$ respondents (56.1\% male and $53.5 \%$ female) child marriage is still in practice in their community. When they were asked whether child marriage was necessary in present time $33.9 \%$ said yes. The supported child marriage as it was considered as a community practice.

Table 5: Need of Family Permission

\begin{tabular}{|l|l|l|l|l|}
\hline \multirow{2}{*}{ Gender } & \multicolumn{2}{|l|}{ Family permission for marriage } & $\begin{array}{l}\text { Not answered } \\
\text { (Percentage) }\end{array}$ & $\begin{array}{l}\text { Total } \\
\text { (Percentage) }\end{array}$ \\
\cline { 2 - 5 } & Yes (Percentage) & No (Percentage) & 41 (100) \\
\hline Male & $34(82.9)$ & $5(12.1)$ & $2(4.8)$ & $71(100)$ \\
\hline Female & $64(90.1)$ & $6(8.4)$ & $1(1.4)$ & $112(100)$ \\
\hline
\end{tabular}

Marriage is an important phase in life. In Indian culture many things such as caste, economic wellbeing, community practice etc. are essential while making marriage relations. According to $82.9 \%$ male respondent and $90.1 \%$ female respondent permission from family is essential for marriage. 


\subsection{YOUTH AWARENESS ABOUT LEGAL PROVISIONS RELATED TO MARRIAGE}

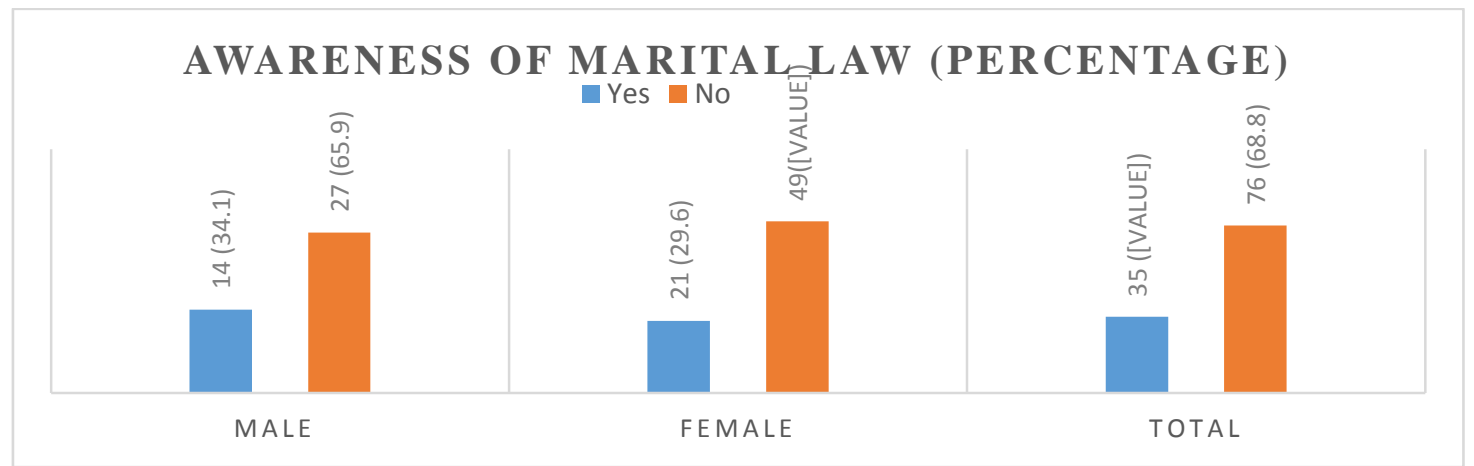

Graph 3: Awareness about marital law (gender wise distribution)

Graph 3 shows that $70.4 \%$ female and $65.9 \%$ male are not aware about the legal provisions of marriage. Only $31.3 \%$ respondents said that they knew legally fixed age of marriage.

$\mathrm{H}_{03}=$ There is no significant difference in awareness of marital laws among youth of different level of education.

$\mathrm{p}$ value at degree of freedom 5 and significant level 0.05 is found 0.015 which is less than 0.05 . Hence $\mathrm{p}$ value is significant and null hypothesis is rejected.

Therefore, there is significant difference in awareness of marital laws among youth of different level of education.

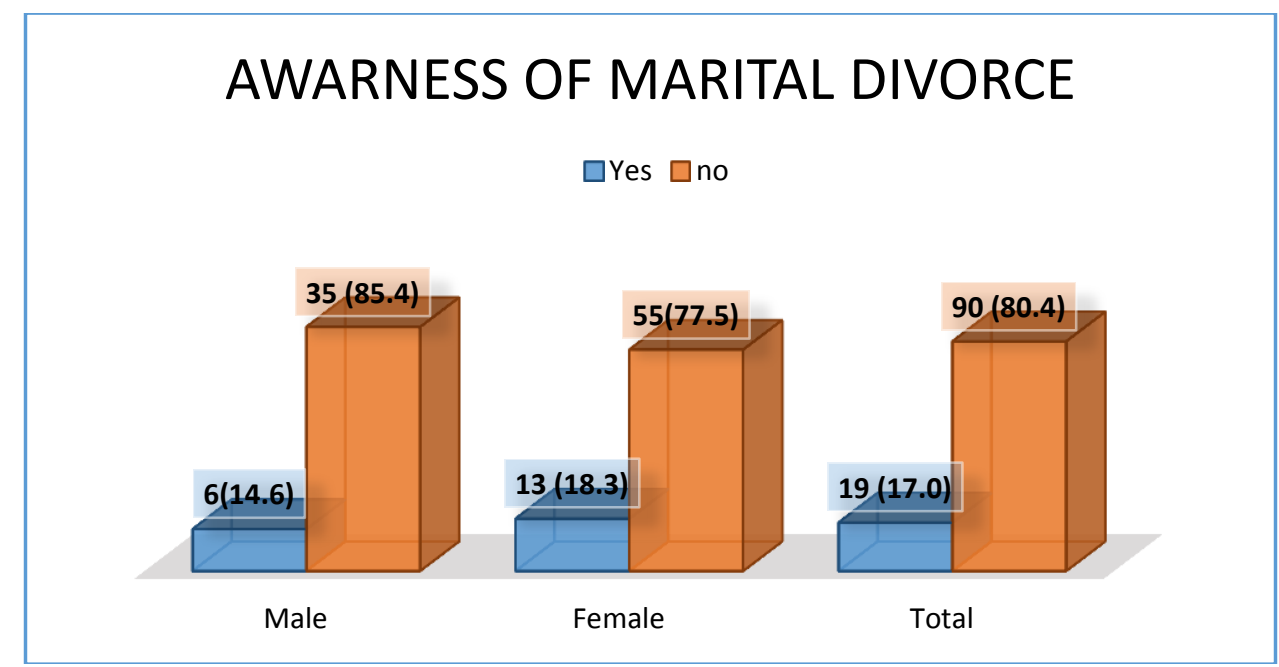

Graph 4: Awareness about marital law (gender wise distribution)

The graph no. 4 indicates that $85.4 \%$ male and $77.5 \%$ female were unaware of legal provisions associated with divorce from marital relationship. Only $17 \%$ respondent said that they knew existence of some provisions for marital divorce but were not aware about the procedures.

$\mathrm{H}_{04}=$ There is no significant difference in awareness of marital divorce among youth of different level of education. 
$\mathrm{p}$ value at degree of freedom 5 and significant level 0.05 is found 0.271 which is greater than 0.05 . Hence $\mathrm{p}$ value is not significant and null hypothesis is accepted.

Therefore, there is no significant difference in awareness of marital divorce among youth of different level of education.

\subsection{PERCEPTION OF YOUTH ON ORGANIZATION OF MARRIAGE CEREMONY}

Table 6: Gender wise distribution about perception of youth on organisation of marriage ceremony

\begin{tabular}{|l|l|l|l|}
\hline \multirow{2}{*}{ Marriage ceremony } & \multicolumn{2}{|l|}{ Gender } & $\begin{array}{l}\text { Total } \\
\text { (Percentage) }\end{array}$ \\
\cline { 2 - 4 } Simple & Male (Percentage) & Female (Percentage) & $84(75.0)$ \\
\hline Luxurious & $37(90.2)$ & $47(66.1)$ & $11(9.8)$ \\
\hline $\begin{array}{l}\text { Neither very simple nor } \\
\text { very luxurious }\end{array}$ & $0(0)$ & $11(15.4)$ & $6(5.3)$ \\
\hline Not answered & $4(9.7)$ & $2(2.8)$ & $11(9.8)$ \\
\hline Total & $0(0)$ & $11(15.4)$ & $112(100)$ \\
\hline
\end{tabular}

Although marriage rituals are not similar in different communities but people in every community put effort to make this special occasion of life very special. Here the question is how much resource one should utilize for his/her marriage. Amin \& Bajracharya (2011) mentioned cost of marriage as driver of social change. They suggested that marriage costs and their correlates were needed to be taken into account in order to promote healthy transition to adulthood.

The respondents were asked what type of marriage they support in terms of spending money, and utilizing resource. $90.2 \%$ male and $66.1 \%$ female supported simple marriage. $15.4 \%$ female favored luxurious marriage and $9.7 \%$ male preferred marriage which is neither very simple nor very luxurious. Respondents supported simple marriage as it is economically viable. According to respondents simple marriage restricts unnecessary guests. Some respondents supported simple marriage as they did not like luxurious celebrations. Respondent favored luxurious marriage as community tradition promotes luxurious marriage and such marriage provides sense of respect in community.

$\mathrm{H}_{05}=$ There is no significant difference in perception towards celebration of marriage ceremony between male and female.

p value at degree of freedom 2 and significant level 0.05 is found 0.008 which is less than 0.05 . Hence $\mathrm{p}$ value is significant and null hypothesis is rejected.

Therefore, there is significant difference in perception towards celebration of marriage ceremony between male and female. 


\subsection{EXPECTATION FROM MARITAL RELATIONSHIP}

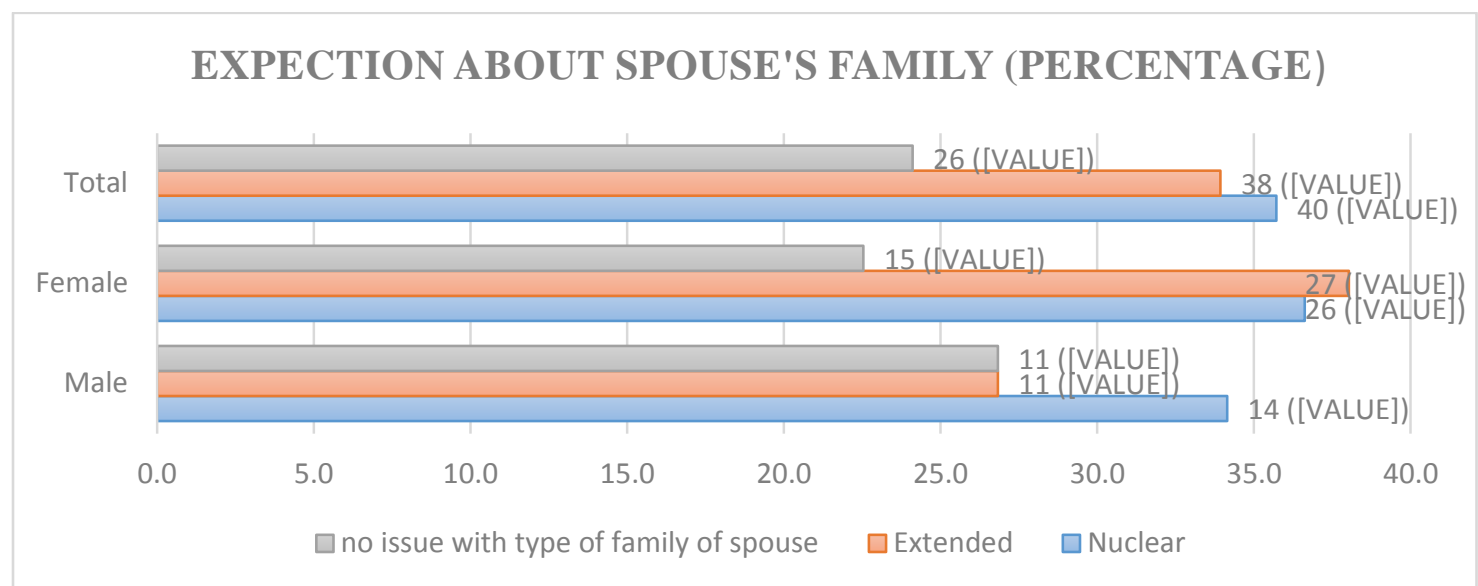

Graph 5: Expectation about spouse family environment (gender wise distribution)

Expectations and understanding are the part of every relationship and in marital relationship also. There are not much differences in the expectations of respondents about their spouse's family type. Spouse from nuclear family was preferred my majority of respondent (35.7\%). Only in case of female majority $38.0 \%$ shared their interest to have spouse from extended families. $24.1 \%$ respondents did not have any issue with the type of family of spouse.

Table 9: Opinion of youth on remarriage, employment of spouse, and physical condition of

\begin{tabular}{|l|l|l|l|}
\hline $\begin{array}{l}\text { Opinion on } \\
\text { remarriage }\end{array}$ & Male (Percentage) & Female (Percentage) & Total (Percentage) \\
\hline Yes & $20(48.7)$ & $29(40.8)$ & $49(43.7)$ \\
\hline No & $17(41.4)$ & $39(54.9)$ & $56(50.0)$ \\
\hline $\begin{array}{l}\text { Not } \\
\text { answered }\end{array}$ & $4(9.7)$ & $3(4.2)$ & $7(6.2)$ \\
\hline Total & $\mathbf{4 1}(\mathbf{1 0 0})$ & $\mathbf{7 1 ~ ( 1 0 0 )}$ & $\mathbf{1 1 2}(\mathbf{1 0 0 )}$ \\
\hline $\begin{array}{l}\text { Opinion on } \\
\text { employment } \\
\text { of spouse }\end{array}$ & Male (Percentage) & Female (Percentage) & Total (Percentage) \\
\hline Yes & $19(46.3)$ & $56(78.8)$ & $75(66.9)$ \\
\hline No & $20(48.7)$ & $11(15.4)$ & $31(27.6)$ \\
\hline $\begin{array}{l}\text { Not } \\
\text { answered }\end{array}$ & $2(4.8)$ & $4(3.5)$ & $6(5.3)$ \\
\hline Total & $\mathbf{4 1 ( 1 0 0 )}$ & $\mathbf{7 1 ( 1 0 0 )}$ & $\mathbf{1 1 2 ( 1 0 0 )}$ \\
\hline $\begin{array}{l}\text { Opinion on } \\
\text { physically } \\
\text { challenged } \\
\text { spouse }\end{array}$ & Male (Percentage) & Female (Percentage) & Total (Percentage) \\
\hline Yes & $13(31.7)$ & $14(19.7)$ & $27(24.2)$ \\
\hline No & $26(63.5)$ & $50(70.4)$ & $76(67.8)$ \\
\hline Not & $2(4.8)$ & $7(9.8)$ & 9 \\
\hline
\end{tabular}




\begin{tabular}{|l|l|l|l|}
\hline answered & & & \\
\hline Total & $\mathbf{4 1 ( 1 0 0 )}$ & $\mathbf{7 1 ( 1 0 0 )}$ & $\mathbf{1 1 2 ( 1 0 0 )}$ \\
\hline
\end{tabular}

$\mathrm{H}_{06}=$ There is no significant difference in opinion on remarriage between male and female.

$\mathrm{p}$ value at degree of freedom 2 and significant level 0.05 is found 0.309 which is greater than 0.05 . Hence $\mathrm{p}$ value is significant and null hypothesis is accepted.

Therefore, there is no significant difference in opinion on remarriage between male and female.

$\mathrm{H}_{07}=$ There is no significant difference in opinion on employment status of spouse between male and female.

$\mathrm{p}$ value at degree of freedom 2 and significant level 0.05 is found 0.000 which is less than 0.05 . Hence $\mathrm{p}$ value is significant and null hypothesis is rejected.

Therefore, there is significant difference in opinion on employment status of spouse between male and female.

$\mathrm{H}_{08}=$ There is no significant difference in acceptance of physically challenged spouse between male and female.

$\mathrm{p}$ value at degree of freedom 2 and significant level 0.05 is found 0.200 which is greater than 0.05 . Hence $\mathrm{p}$ value is significant and null hypothesis is accepted.

Therefore, there is no significant difference in acceptance of physically challenged spouse between male and female.

\section{CONCLUSION}

Different people see marriage differently. Some youth in the study said that without parents' permission marriage is incomplete whereas some youth opposed pressure by family members for marriage. There were respondents who opposed child marriage and on the other hand some respondents spoke in favor of child marriage. Overall it was found that community and culture have influence on youth's decision about marriage. But at the same time they should also be able to understand what is beneficial for them and the future generation. For this pre-marital counselling facilities need to be arranged for young people who have crossed legally fixed marriage age. Information related to legal provisions for marriage and divorce are not known to majority of members of the community. Legal provisions should be a part of marital counselling. However it is also essential to work with Women and Child development department, panchayat members, teachers and parents to stop practices like child marriage and to promote education in the community.

\section{REFERENCES}

[1] Adolescents in India: A desk review of existing evidence and behaviours, programmes and Policies. (2013). UNICEF, New Delhi, India 
[2] Amin, S. \& Bajracharya, A. (2011). Costs of marriage-Marriage transactions in the developing world. Promoting healthy, safe and productive transactions to adulthood, Brief no. 35. www.popcouncil.org/publication/serialsbriefs/TABriefs.asp

[3] Bhale, A. G. (2013). Perspective of Educated Youth towards inter caste marriage. IJAAR. Vol. 1 No. 1, pp. 18-28

[4] Bhasin, V. (2007). Status of Tribal Women in India. SHCS. Vol. 1 no. 1, pp. 1-16

[5] D.B Kuppe Gram Panchayat, www.panchamitra.kar.nic.in

[6] Mishra, A.N., Banerjee, A.K., \& Kumari, R. (2015). A study of effect of education on Attitude towards Inter Caste marriage in Rural Punjab, India. International Journal of Social Sciences and Humanities Research. Vol. 3, Issue. 1, pp. 439- 443

[7] Mitra, $N$ \& Parasuramn, S. (2015). Child marriage \& Early Motherhood: Understanding from lived experiences of young people. Center of Excellence on adolescents and Youth. Tata Institute of Social Sciences.

[8] Upadhyay, S.K. \& Gupta, P. (2013). Marriage, Process and Preparedness among youth: Insights from Indian Youth. International Institute for Population Sciences, Mumbai, India.

[9] Dodda Birana Koppe Gram Panchayat Profile, www.panchamitra.kar.nic.in 